\title{
Pengaruh Mathematical Resilience terhadap Kemampuan Pemecahan Masalah Matematis Siswa
}

\author{
Faiqatul 'Athiyah', Ulumul Umah ${ }^{2 *)}$, \& Tomy Syafrudin ${ }^{3}$ \\ 1,2,3 Universitas Pesantren Tinggi Darul Ulum Jombang
}

\begin{tabular}{l}
\hline INFO ARTICLES \\
\hline Article History: \\
Received: 27-11-2019 \\
Revised: 7-1-2020 \\
Approved: 28-02-2020 \\
Publish Online: 16-06-2020 \\
\hline Key Words: \\
Mixed Methods, Mathematical \\
Resilience, Mathematical Problem \\
Solving
\end{tabular}

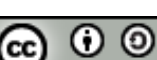

This article is licensed under a Creative Commons AttributionShareAlike 4.0 International License.

\begin{abstract}
This study aims to determine the influence of students' mathematical resilience on their mathematical problem-solving ability, and describe students' problem solving ability based on their mathematical resilience level. This study is a mix method research with embedded concurred type. Quantitative method as the main method was used to test the effect of mathematical resilience on students' mathematical problem solving abilities statistically. Furthermore, qualitative method was used as complementary method to further analyze students' problem solving abilities based on their level difference in mathematical resilience. The results obtained from this research were (1) students' mathematical resilience affected their mathematical problem-solving ability significantly, (2) the influence of mathematical resilience on students' mathematical problem-solving ability was $32,7 \%$, (3) in general, students with high mathematical resilience were able to solve problems with interpretation, strategies and arithmetic operation well, but there were also students who make mistakes in arithmetic operations. Some students with average mathematical resilience had difficulties in problem interpretation.
\end{abstract}

\begin{abstract}
Abstrak: Penelitian ini bertujuan untuk menguji pengaruh mathematical resilience terhadap kemampuan pemecahan masalah matematis siswa serta mendeskripsikan perbedaan kemampuan pemecahan masalah siswa berdasar pada tingkat mathematical resilience. Penelitian ini merupakan penelitian kombinasi (mix method) tipe concurered embedded Metode kuantitatif sebagai metode utama digunakan untuk menguji pengaruh mathematical resilience terhadap kemampuan pemecahan masalah matematis siswa secara statistik. Selanjutnya metode kualitatif digunakan sebagai metode pelengkap untuk menganalisis lebih jauh kemampuan pemecahan masalah siswa berdasarkan perbedaan tingkat mathematical resilience.. Hasil yang diperoleh dari penelitian ini adalah (1) terdapat pengaruh mathematical resilience terhadap kemampuan pemecahan masalah matematis siswa, (2) besar pengaruh mathematical resilience terhadap kemampuan pemecahan masalah matematis siswa adalah $32,7 \%$, (3) secara umum siswa dengan mathematical resilience tinggi mampu menyelesaikan soal dengan interpretasi, strategi, dan operasi hitung yang baik. Siswa dengan mathematical resilience sedang, mengalami kesulitan dalam menginterpretasikan masalah.
\end{abstract}

Correspondence Address: Kompleks PP. Darul Ulum Peterongan, Jombang, 61481, Indonesia; e-mail: ulumul.ummah@gmail.com

How to Cite (APA $6^{\text {th }}$ Style): 'Athiyah, F., Umah, U., \& Syafrudin, T. (2020). Pengaruh Mathematical Resilience Terhadap Kemampuan Pemecahan Masalah Matematis Siswa. JKPM (Jurnal Kajian Pendidikan Matematika), 5(2): 223-234.

Copyright: 'Athiyah, F., Umah, U., \& Syafrudin, T., (2020)

Competing Interests Disclosures: The authors declare that they have no significant competing financial, professional or personal interests that might have influenced the performance or presentation of the work described in this manuscript. 


\section{PENDAHULUAN}

Pemecahan masalah merupakan aspek yang harus menjadi bagian dari proses pembelajaran matematika dengan karakteristik saintifik yang tercermin dalam rumusan standar proses pembelajaran dalam Peraturan Menteri Pendidikan dan Kebudayaan No.22 tahun 2016 (Kemendikbud, 2016). Pada proses pembelajaran matematika, National Council of Teacher of Mathematics menyebutkan secara tegas tentang standar kemampuan pemecahan masalah yang harus dimiliki oleh siswa. Hal ini menunjukkan bahwa pemecahan masalah merupakan kompetensi yang harus ditanamkan kepada siswa agar memiliki keterampilan untuk menghadapi masalah di dunia nyata (NCTM, 2002).

Berdasar pada wawancara yang dilakukan oleh peneliti dengan salah satu guru matematika di MA Al-Ishlah Bilapora Barat Ganding Sumenep, masih ditemui kasus beberapa siswa kesulitan menyelesaikan masalah matematis baru dalam konteks yang sedikit berbeda dari contoh soal yang diberikan sebelumnya. Hal ini mengindikasikan bahwa siswa hanya sebatas mengetahui langkah prosedural, siswa kesulitan dalam memodelkan dan menemukan strategi penyelesaian masalah yang tepat. Fenomena serupa tidak hanya ditemui di satu sekolah tersebut, tetapi juga di sekolah-sekolah lain di Indonesia yang dapat diamati dari hasil-hasil penelitian antara lain Harahap \& Surya (2017), Akbar, Hamid, Bernard, \& Sugandi (2018), dan Utami \& Wutsqa (2017). Secara lebih luas, berdasarkan hasil PISA (Programme for International Student Assessment) tahun 2015 (OECD, 2019), kemampuan siswa Indonesia dalam matematika masih tergolong rendah.

Dalam memecahkan masalah matematika, siswa dituntut untuk berpikir tingkat tinggi sehingga mereka harus bekerja keras dan tidak mudah menyerah ketika membuat. Oleh karena itu, dibutuhkan sikap tekun dan tangguh dalam menghadapi tantangan atau kesulitan dalam belajar matematika atau disebut sebagai mathematical resilience (Johnston-Wilder \& Lee, 2010). Kooken, Welsh, McCoach, JohnstonWilder, \& Lee (2016) menyatakan bahwa matematikawan yang luar biasa harus bekerja keras bahkan membuat kesalahan ketika belajar dan memecahkan masalah matematika. Kooken et al., (2016) mendeskripsikan mathematical resilience sebagai sikap positif dalam menghadapi kesulitan dalam banyak bentuk diantaranya yaitu malu karena kinerja yang buruk, rasa bosan, kegagalan, dan kecemasan kinerja selama di dalam kelas atau ketika mengerjakan tes. Yeager \& Dweck (2012) menyebut resiliensi sebagai sikap "tangguh" dari setiap perilaku, atribusi, atau respons emosional untuk tantangan akademis atau sosial yang positif dan bermanfaat untuk pengembangan (seperti mencari strategi baru, menempatkan upaya yang lebih besar, atau memecahkan permasalahan dengan baik).

Beberapa penelitian menunjukkan kecenderungan pengaruh positif dari mathematical resilience terhadap berbagai aspek dalam kemampuan matematika. Dilla, Hidayat, \& Rohaeti (2018) menemukan bahwa semakin tinggi pengaruh tingkat mathematical resilience siswa menyebabkan semakin tinggi kemampuan berpikir kreatif matematis mereka. Sementara itu, hasil penelitian Cahyani, Wulandari, Rohaeti, \& Fitrianna (2018) menunjukkan bahwa mathematical resilience memberikan kontribusi sebesar $49,9 \%$ terhadap kemampuan pemahaman matematis siswa. Siswa dengan mathematical resilience yang tinggi juga memiliki kecenderungan kemampuan komunikasi matematis yang baik (Kurnia, Royani, Hendiriana, \& Nurfauziah, 2018).

Sedangkan terkait dengan kemampuan pemecahan masalah, Maharani \& Bernard (2018) telah menunjukkan adanya hubungan yang signifikan antara mathematical resilience dan kemampuan pemecahan masalah siswa, namun penelitiannya terbatas pada masalah matematika topik lingkaran serta lebih berfokus pada penyebab kesulitan siswa pada pemecahan masalah. Jadi, seberapa signifikan mathematical resilience mempengaruhi kemampuan pemecahan masalah secara lebih luas perlu diinvestigasi lebih lanjut. Penelitian ini bertujuan untuk menguji signifikansi pengaruh mathematical resilience terhadap kemampuan pemecahan 
masalah serta mendeskripsikan perbedaan pemecahan masalah siswa dengan tingkat mathematical resilience yang berbeda. Cakupan topik matematika yang diujikan pada subjek penelitian ini yaitu aplikasi barisan dan deret yang berbeda dengan penelitian terdahulu. Hasil penelitian diharapkan dapat memberikan kontribusi teori dalam rangka upaya-upaya peningkatan kemampuan siswa dalam pemecahan masalah.

\section{METODE}

Jenis penelitian ini merupakan penelitian kombinasi (mixed method) yaitu penelitian dengan menggabungkan data kuantitatif dan data kualitatif. Metode kombinasi yang digunakan peneliti dengan menggunakan pendekatan concurrent embedded dengan metode kuantitatif sebagai metode primer (utama) dan metode kualitatif sebagai metode sekunder (pelengkap). Adapun tahapan penelitian ini dapat dijelaskan melalui diagram berikut.

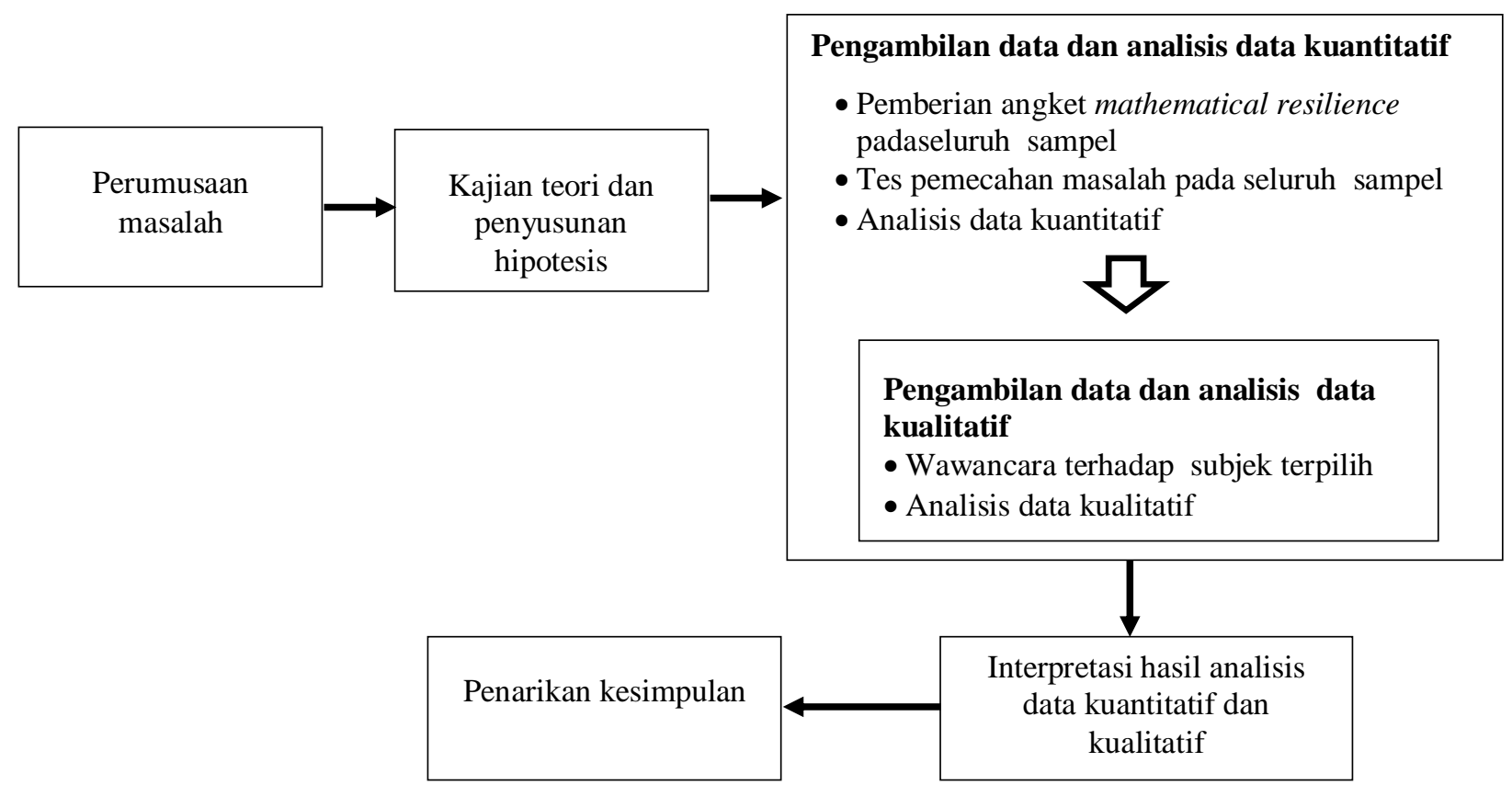

\section{Gambar 1. Diagram Tahapan Penelitian}

Populasi dalam penelitian ini adalah seluruh siswa XI MA Al-Ishlah. Teknik pengambilan sampel menggunakan purposive sampling agar dapat menjelaskan tingkat kemampuan pemecahan masalah berdasarkan tingkat mathematical resilience siswa yang berbeda. Dari populasi tersebut dipilih sampel penelitian dengan memilih siswa kelas XI IPS yang terdiri dari 30 siswa karena siswa di kelas tersebut memiliki semangat belajar dan persepsi terhadap matematika yang lebih beragam dibandingkan dengan kelas IPA. Kemudian untuk mengumpulkan data kualitatif, dua subjek dari masing-masing tingkatan mathematical resilience dipilih untuk diwawancarai. Pemilihan subjek didasarkan pada kemampuan mengungkapkan pendapat dengan baik yang dapat diketahui berdasarkan informsi dari guru matematika, wali kelas, dan teman sekelas siswa tersebut.

Instrumen penelitian ini berupa kuesioner mathematical resilience, tes kemampuan pemecahan masalah, dan pedoman wawancara yang telah divalidasi. Data mengenai tingkat mathematical resilience 
siswa diperoleh melalui kuesioner berdasarkan aspek nilai, perjuangan, dan perkembangan yang diadaptasi dari Kooken et al., (2016) sebagai berikut pada Tabel 1.

Tabel 1. Indikator Penilaian Mathematical Resilience

\begin{tabular}{|c|c|}
\hline Aspek yang dinilai & Indikator \\
\hline Nilai & $\begin{array}{l}\text { - sejauh mana siswa menemukan pentingnya belajar matematika dalam } \\
\text { mencapai tujuan mereka saat ini atau masa depan } \\
\text { - sejauh mana siswa merasakan matematika menjadi mata pelajaran } \\
\text { berharga yang diyakini berkorelasi positif dengan tingkat motivasi untuk } \\
\text { mempelajarinya }\end{array}$ \\
\hline Perjuangan & $\begin{array}{l}\text { - anggapan bahwa siswa kadang-kadang perlu membuat banyak usaha untuk } \\
\text { belajar matematika } \\
\text { - anggapan bahwa bahkan ahli matematika yang luar biasa pun harus } \\
\text { bekerja sangat keras untuk belajar, memecahkan masalah matematika, dan } \\
\text { membuat kesalahan dalam proses }\end{array}$ \\
\hline Perkembangan & $\begin{array}{l}\text { - percaya bahwa jika seseorang bekerja pada suatu bidang tertentu mereka } \\
\text { dapat mempelajari lebih lanjut }\end{array}$ \\
\hline
\end{tabular}

Sementara itu, teknik tes digunakan untuk memperoleh data kemampuan pemecahan masalah. Setelah soal tes divalidasi oleh validator ahli, soal tes pemecahan masalah diujicobakan terlebih dahulu kepada kelompok kecil siswa untuk uji keterbacaan. Untuk mendapatkan skor kuantitatif kemampuan pemecahan masalah siswa, peneliti menggunakan rubrik penilaian pemecahan masalah dari The Math Forum at NCTM (NCTM, 2016) yang memuat 3 aspek dalam pemecahan masalah, yaitu: interpretasi (interpretation), strategi (strategy), dan akurasi (accuracy) seperti yang dijabarkan pada Tabel 2.

Tabel 2 Indikator Penilaian Kemampuan Pemecahan Masalah

\begin{tabular}{ll}
\hline \multicolumn{1}{c}{ Aspek yang dinilai } & \multicolumn{1}{c}{ Indikator } \\
\hline Interpretasi & memahami kondisi soal dengan mengidentifikasi data yang \\
& diketahui, ditanyakan dan kecukupan data untuk permasalahan \\
Strategi & menggunakan strategi yang tepat, seperti menemukan pola, \\
& membuat tabel atau grafik, atau membuat model lain yang sudah \\
& direncanakan \\
Akurasi & melakukan perhitungan dan memberikan kesimpulan dengan tepat \\
\hline
\end{tabular}

Analisis data kuantitatif dilakukan dengan menggunakan uji regresi linier sederhana untuk mengetahui pengaruh mathematical resilience terhadap kemampuan pemecahan masalah matematis siswa. Dalam hal ini, mathematical resilience berperan sebagai variabel bebas dan kemampuan pemecahan masalah matematis sebagai variabel terikat. Namun sebelum dilakukan uji regresi linier sederhana peneliti menggunakan uji asumsi yaitu uji normalitas data, uji heteroskedastisaitas, dan uji autokorelasi. Selanjutnya analisis data kualitatis dilakukan berdasarkan model Miles and Huberman (Sugiyono, 2017) yang meliputi 
reduksi data, penyajian data, serta penarikan kesimpulan dan verifikasi. Data kuantitatif diperoleh dengan teknik wawancara berdasarkan jawaban tertulis siswa.

\section{HASIL}

Penelitian ini diuraikan berdasarkan hasil penelitian pada dua tahapan yaitu kuantitatif dan kualitatif. Tahapan ini dimaksudkan untuk mengetahui dan mendeskripsikan pengaruh mathematical resilience terhadap kemampuan pemecahan masalah matematis siswa. Berdasarkan hasil kuesioner mathematical resilience dan tes pemecahan masalah yang diberikan diperoleh data sebagai berikut.

Tabel 3. Tingkat mathematical resilience siswa

\begin{tabular}{ll}
\hline Tingkat Mathematical Resilience & Banyaknya Siswa \\
\hline Tinggi & 10 \\
Sedang & 20 \\
Rendah & 0 \\
\hline
\end{tabular}

Berdasar pada Tabel 3 dapat diketahui bahwa lebih banyak siswa memiliki tingkat mathematical resilience sedang serta tidak ditemukan siswa dengan mathematical resilience rendah. Hasil tes pemecahan masalah juga menunjukkan mayoritas siswa berada pada level menengah (baik dan cukup) seperti yang ditunjukkan pada Tabel 4. Sementara itu, Tabel 5 menunjukkan bahwa siswa dengan mathematical resilience tinggi dapat melakukan pemecahan masalah minimal pada kategori cukup, sedangkan siswa dengan mathematical resilience sedang tidak ada yang dapat menyelesaikan masalah matematis dengan sempurna bahkan ada yang berada pada kategori kurang atau amat kurang.

Tabel 4. Tingkat kemampuan pemecahan masalah matematis siswa

\begin{tabular}{ll}
\hline Tingkat kemampuan pemecahan masalah & Banyaknya Siswa \\
\hline Istimewa & 1 \\
Amat baik & 5 \\
Baik & 14 \\
Cukup & 7 \\
Kurang & 1 \\
Amat kurang & 2 \\
\hline
\end{tabular}

Tabel 5. Tingkat kemampuan pemecahan masalah matematis siswa

berdasarkan kategori tingkat mathematical resilience

\begin{tabular}{lllllll}
\hline \begin{tabular}{l} 
Tingkat $\begin{array}{l}\text { Mathematical } \\
\text { Resilience }\end{array}$ \\
\cline { 2 - 7 }
\end{tabular} & \multicolumn{2}{l}{$\begin{array}{l}\text { Banyaknya Siswa pada } \\
\text { pemecahan masalah }\end{array}$} \\
\cline { 2 - 7 } & Istimewa & $\begin{array}{l}\text { Amat } \\
\text { Baik }\end{array}$ & Baik & Cukup & Kurang & $\begin{array}{l}\text { Amat } \\
\text { Kurang }\end{array}$ \\
\hline Tinggi & 1 & 3 & 5 & 1 & 0 & 0 \\
Sedang & 0 & 2 & 9 & 6 & 1 & 2 \\
Rendah & 0 & 0 & 0 & 0 & 0 & 0 \\
\hline
\end{tabular}


Sebelum melakukan uji regresi sederhana untuk mengetahui pengaruh mathematical resilience terhadap kemampuan pemecahan masalah matematis siswa, uji asumsi dilakukan terlebih dahulu, yaitu meliputi uji normalitas, uji heteroskedastisitas, dan uji autokorelasi. Berdasarkan hasil uji normalitas dengan menggunakan IBM SPSS Statistics 22, diperoleh nilai signifikansi sebesar 0,106. Hal ini menunjukkan

bahwa sampel berasal dari populasi yang berdistribusi normal karena nilai signifikansi lebih besar dari $0,05(0,106>0,05)$. Berdasarkan hasil uji Glejser diperoleh nilai signifkansi sebesar 0,179 yang

menunjukkan tidak terjadi heteroskedastisitas karena nilai signifikansi lebih besar dari $0,05(0,179>0,05)$. Berdasarkan hasil uji autokorelasi yang dilihat dari nilai Durbin-Watson sebesar

1,980 , nilai tersebut terletak pada interval $d u<D W<4-d u$ atau $1,4894<1,980<2,5106$, sehingga dapat disimpulkan bahwa tidak terjadi autokorelasi.

Berdasar pada hasil uji asumsi di atas dapat disimpulkan bahwa data yang diperoleh telah memenuhi syarat untuk dapat dianalisis lebih lanjut dengan uji regresi linier sederhana. Berikut hasil analisis regresi linier sederhana.

Tabel 6. ANOVA ${ }^{\mathrm{a}}$

\begin{tabular}{llllll}
\hline Model & Sum of Square & D & Mean Square & F & Sig \\
& & & & & \\
\hline Regression & 2128,903 & 1 & 2128,903 & 13, & 0,0 \\
Resiu & 4383,074 & 2 & 156,538 & & \\
Total & 6511,977 & 2 & & & \\
& & & & &
\end{tabular}

a. Dependent variabel: Pemecahan Masalah

b. Predictor: (Constant), mathematical resilience

Tabel ANOVA digunakan untuk menjelaskan apakah ada pengaruh yang signifikan antara mathematical resilience terhadap kemampuan pemecahan masalah matematis. Hipotesis yang diajukan adalah:

$\mathrm{H}_{0}$ : tidak ada pengaruh mathematical resilience terhadap kemampuan pemecahan masalah matematika siswa

$\mathrm{H}_{\mathrm{a}}$ : ada pengaruh mathematical resilience terhadap kemampuan pemecahan masalah matematika siswa

Pada Tabel 6 diperoleh bahwa $F_{\text {hitung }}=13,600$ dengan tingkat signifikansi $0,001<0,05$, maka dengan demikian $H_{0}$ ditolak, yang berarti bahwa ada pengaruh yang signifikan antara mathematical resilience terhadap kemampuan pemecahan masalah matematis.

Besar pengaruh mathematical resilience siswa terhadap kemampuan pemecahan masalah adalah sebesar $32,7 \%$ sedangkan sisanya yaitu $67,3 \%$ dipengaruhi oleh variabel lain di luar penelitian ini. Hal ini

berdasarkan nilai koefisien determinasi ( $R$ Square) pada uji regresi linier sederhana pada Tabel 7.

Tabel 7. Hasil uji regresi linear sederhana koefisien determinasi

\begin{tabular}{lllll}
\hline Model & $\mathrm{R}$ & $\mathrm{R}$ Square & Adjusted R Square & Std. Errod of the Estimate \\
\hline 1 & $0,572^{\mathrm{a}}$ & 0,327 & 0,303 & 12,51153 \\
\hline
\end{tabular}

a. Predictors: (Constant), mathematical resilience 


\section{b. Dependent variabel: pemecahan masalah}

Berdasar pada asil wawancara terhadap 2 subjek dengan mathematical resilience tinggi serta 2 subjek dengan mathematical resilience rendah diperoleh hasil analisis data kualitatif pada Tabel 8. Pada tes pemecahan masalah, siswa diminta menjawab pertanyaan dengan topik aplikasi barisan dan deret. Pada soal pertama, siswa diminta menentukan kapasitas tempat duduk ketika banyaknya tempat duduk tiap baris membentuk barisan aritmatika dengan suku ke-2 dan ke-7 diketahui. Pada soal kedua, masih dalam konteks soal pertama, siswa diminta menentukan harga tiket termurah jika harga untuk setiap baris memiliki selisih 5.000 rupiah jika diketahui total harga seluruh tiket yang tersedia.

Berdasarkan analisis data kualitatif, subjek dengan mathematical resilience tinggi cenderung lebih baik dalam memilih dan menerapkan strategi pemecahan masalah. Subjek 1 dapat menyelesaikan kedua soal dengan baik dan memperoleh jawaban akhir yang tepat (Gambar 2), sedangkan subjek 2 telah menginterpretasikan masalah dan menggunakan strategi dengan benar namun mengalami kesalahan perhitungan sehingga jawaban akhir kurang tepat. Sementara itu, subjek dengan mathematical resilience sedang dapat menyelesaikan masalah pertama dengan baik tetapi kurang tepat dalam membuat pemodelan matematis pada soal kedua (Gambar 3), bahkan Subjek 4 tidak dapat menjawab untuk soal kedua (Gambar 4).

Tabel 8. Perbandingan kemampuan pemecahan masalah pada subjek penelitian

\begin{tabular}{|c|c|c|c|c|}
\hline \multirow[t]{2}{*}{ Subjek } & \multirow[t]{2}{*}{ Kategori } & \multicolumn{3}{|c|}{ Aspek yang dinilai } \\
\hline & & Interpretasi & Strategi & Akurasi \\
\hline Subjek 1 & $\begin{array}{l}\text { Mathematical } \\
\text { resilience tinggi, } \\
\text { pemecahan } \\
\text { masalah istimewa }\end{array}$ & $\begin{array}{l}\text { Mengetahui informasi dalam } \\
\text { soal, mengetahui apa yang } \\
\text { ditanyakan, dan dapat } \\
\text { mengolah informasi dengan } \\
\text { tepat }\end{array}$ & $\begin{array}{l}\text { Menentukan dan } \\
\text { menerapkan } \\
\text { strategi dengan } \\
\text { tepat }\end{array}$ & $\begin{array}{l}\text { Melakukan } \\
\text { operasi hitung } \\
\text { dengan benar } \\
\text { dan menemukan } \\
\text { solusi yang tepat }\end{array}$ \\
\hline Subjek 2 & $\begin{array}{l}\text { Mathematical } \\
\text { resilience tinggi, } \\
\text { pemecahan } \\
\text { masalah sangat } \\
\text { baik }\end{array}$ & $\begin{array}{l}\text { mengetahui informasi yang } \\
\text { ada di dalam soal, mengetahui } \\
\text { apa yang ditanyakan dan } \\
\text { mengolah informasi dengan } \\
\text { tepat }\end{array}$ & $\begin{array}{l}\text { Menentukan dan } \\
\text { menerapkan } \\
\text { strategi dengan } \\
\text { tepat }\end{array}$ & $\begin{array}{l}\text { Melakukan } \\
\text { kesalahan dalam } \\
\text { operasi hitung } \\
\text { sehingga } \\
\text { kesimpulan } \\
\text { kurang tepat }\end{array}$ \\
\hline Subjek 3 & $\begin{array}{l}\text { Mathematical } \\
\text { resilience sedang, } \\
\text { pemecahan } \\
\text { masalah baik }\end{array}$ & $\begin{array}{l}\text { kurang mampu } \\
\text { menginterpretasi informasi } \\
\text { dalam soal, mengetahui apa } \\
\text { yang ditanyakan dalam soal } \\
\text { namun kurang bisa mengolah } \\
\text { informasi dengan tepat }\end{array}$ & $\begin{array}{l}\text { Kurang tepat dalam } \\
\text { menerapkan } \\
\text { strategi yaitu salah } \\
\text { dalam pemodelan } \\
\text { matematis }\end{array}$ & $\begin{array}{l}\text { Melakukan } \\
\text { perhitungan dan } \\
\text { memberikan } \\
\text { kesimpulan } \\
\text { tetapi belum } \\
\text { benar }\end{array}$ \\
\hline Subjek 4 & $\begin{array}{l}\text { Mathematical } \\
\text { resilience sedang, } \\
\text { pemecahan } \\
\text { masalah kurang }\end{array}$ & $\begin{array}{l}\text { Tidak dapat menginterpretasi } \\
\text { informasi yang terdapat di } \\
\text { dalam soal padahal sudah } \\
\text { membaca ulang } 4 \text { kali }\end{array}$ & $\begin{array}{l}\text { Tidak dapat } \\
\text { menentukan } \\
\text { strategi } \\
\text { penyelesaian } \\
\text { masalah }\end{array}$ & $\begin{array}{l}\text { Tidak dapat } \\
\text { menentukan } \\
\text { kesimpulan dari } \\
\text { penyelesaian } \\
\text { masalah }\end{array}$ \\
\hline
\end{tabular}




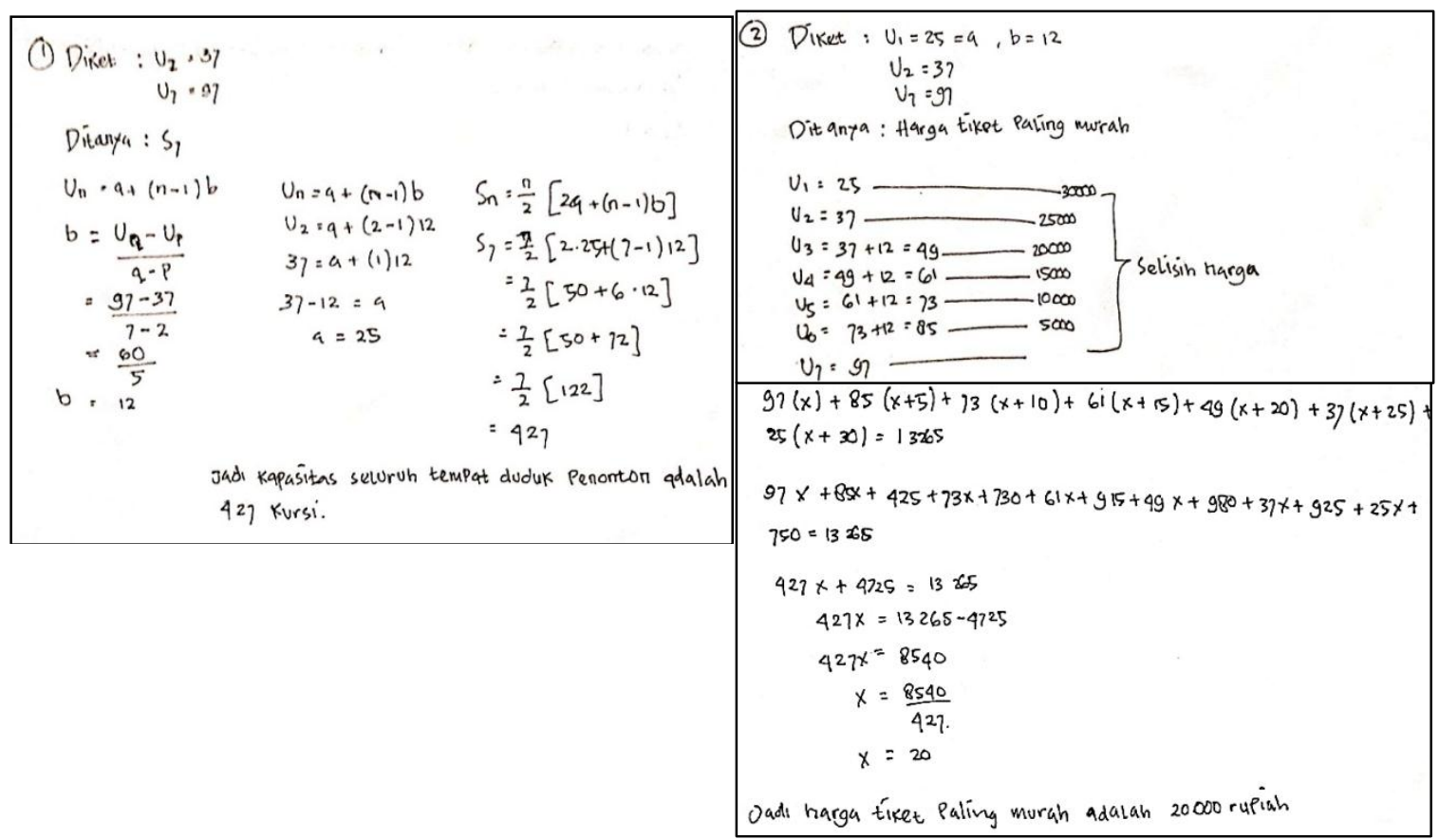

Gambar 2. Subjek mathematical resilience tinggi menunjukkan jawaban yang tepat

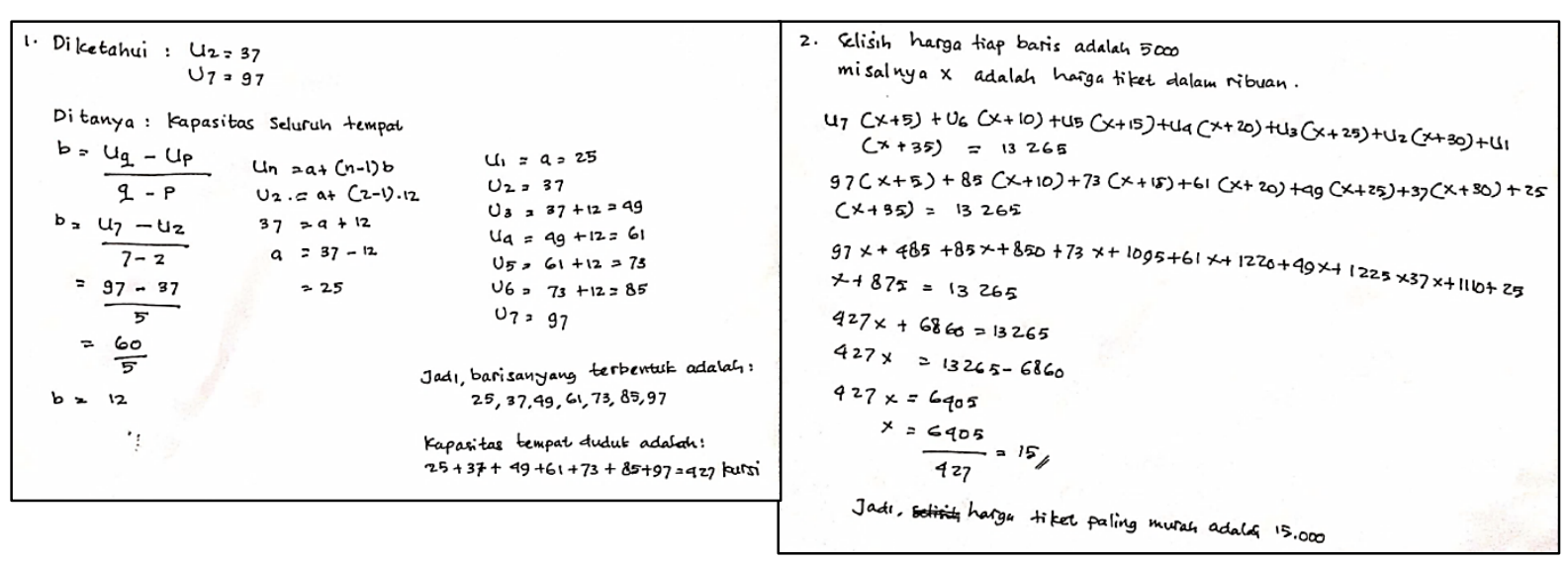

Gambar 3. Subjek mathematical resilience sedang melakukan kesalahan dalam pemodelan matematis untuk soal kedua 


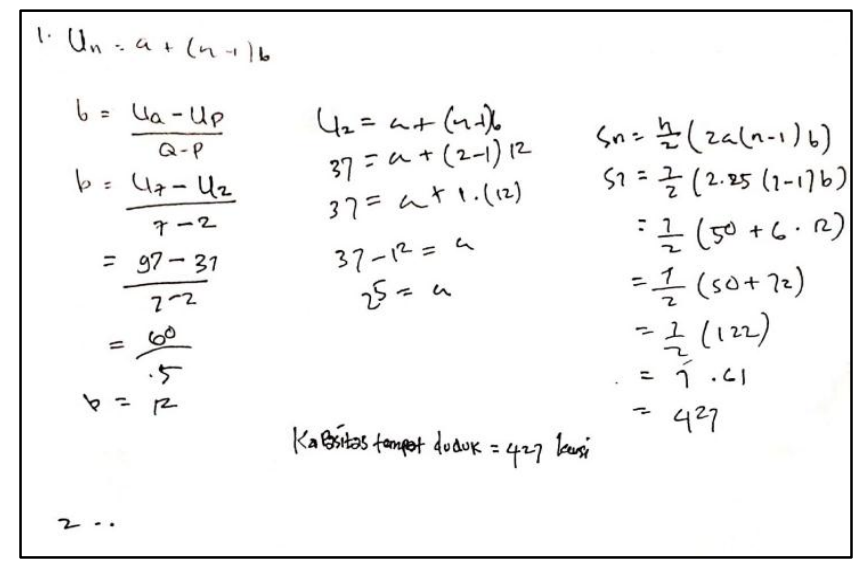

\section{Gambar 4. Subjek mathematical resilience sedang tidak dapat memberikan jawaban untuk soal kedua}

\section{PEMBAHASAN}

Berdasar pads hasil analisis regresi linier sederhana, diperoleh hasil bahwa mathematical resilience berpengaruh secara signifikan terhadap kemampuan pemecahan masalah matematis siswa. Hasil kuesioner mathematical resilience siswa dikategorikan dalam dua kategori yaitu tinggi dan sedang (kategori sedang adalah 20 siswa dan kategori tinggi 10 siswa). Berdasar pada data kuantitatif maupun kualitatif, siswa dengan mathematical resilience tinggi cenderung lebih baik dalam melakukan penyelesaian masalah yang dapat dilihat dari interpretasi masalah dan strategi penyelesaian yang tepat meskipun terdapat siswa yang kurang teliti dalam melakukan perhitungan. Sementara siswa dengan mathematical resilience yang lebih rendah cukup banyak yang kurang baik dalam pemecahan masalah dan beberapa tidak memberikan jawaban ketika masalah semakin kompleks. Hal ini sejalan dengan penelitian yang dilakukan oleh (Maharani \& Bernard, 2018) yaitu siswa dengan kemampuan resiliensi tinggi dapat menyelesaikan soal secara prosedural, namun kurang teliti dan masih rendah dalam perhitungan, sehingga mengakibatkan jawaban yang seharusnya benar menjadi salah.

Siswa dengan mathematical resilience sedang kurang bisa menginterpretasi masalah yang terdapat di dalam soal, dia melakukan kesalahan dalam interpretasi terhadap informasi yang terdapat di dalam soal yaitu ketika menginterpretasi selisih harga dari tiap barisan penonton. Siswa dengan mathematical resilience yang sedang bahkan ada yang tidak dapat menginterpretasi masalah dan menentukan strategi pemecahan masalah, sehingga dia tidak dapat menemukan jawaban dari soal yang diberikan. (Maharani \& Bernard, 2018) dalam penelitiannya mengungkapkan bahwa siswa yang memiliki mathematical resilience tergolong rendah kesulitan memahami masalah dan menentukan strategi untuk menyelesaikan permasalahan, serta mereka juga kurang menguasai konsep. Dalam penelitian ini, siswa yang mengalami kesulitan dalam pemecahan masalah terdapat pada siswa yang memiliki mathematical resilience yang sedang. Sementara itu, Zanthy (2018) mengungkapkan bahwa tingginya resiliensi pada siswa sejalan dengan tingginya motivasi untuk mencapai prestasi akademik. Sementara itu, siswa dengan resiliensi yang lebih rendah cepat merasa frustasi karena adanya kesulitan menjadikannya sebagai beban dan ancaman, sehingga dapat disimpulkan bahwa semakin tinggi mathematical resilience siswa maka semakin tinggi pula kemampuan pemecahan masalah matematis siswa. 
Siswa dengan mathematical resilience tinggi memiliki rasa percaya diri yang tinggi dan tidak khawatir ataupun cemas ketika mengerjakan soal matematika dan tidak menunjukkan sikap gugup ketika menjelaskan hasil pekerjaan mereka selama proses wawancara, sehingga siswa dengan mathematical resilience tinggi tidak mengalami kesulitan dalam mengerjakan tes pemecahan masalah. Siswa dengan mathematical resilience sedang mengalami kesulitan dalam mengerjakan soal pemecahan masalah karena mereka kurang merasa percaya diri ketika menghadapi soal matematika, hal ini ditunjukkan dengan adanya sikap khawatir dan cemas ketika mengerjakan soal dan sikap gugup ketika menjelaskan hasil pekerjaan mereka selama proses wawancara. Hal ini di karenakan mathematical resilience merupakan sikap positif yang berbading terbalik dengan sikap tidak percaya diri dan kecemasan matematika (Kooken et al., 2016). Meskipun demikian, mathematical resilience merupakan sikap yang berpotensi untuk bisa dibentuk dengan lingkungan yang mendukung (Johnston-Wilder, Lee, Garton, Goodlad, \& Brindley, 2013). Hasil penelitian Hutahuruk (2019) juga menunjukkan adanya kecenderungan mathematical resilience mahasiswa yang lebih baik pada kelas problem-based learning daripada kelas konvensional. Hal ini dapat diartikan bahwa kondisi yang menantang yang menuntut mahasiswa untuk melakukan pemecahan masalah justru dapat membentuk lingkungan yang mendukung sikap mathematical resilience yang baik.

Meskipun penelitian-penelitian terdahulu menunjukkan hubungan positif antara mathematical resilience dan kemampuan matematis, dalam penelitian ini ditemukan siswa yang masih memiliki kemampuan pemecahan masalah yang kurang dan sangat kurang, padahal tidak ditemukan siswa dengan mathematical resilience rendah. Hal ini dapat diduga sebagai hasil peran faktor lain yang mempengaruhi kemampuan pemecahan masalah seseorang karena hasil penelitian ini menunjukkan bahwa mathematical resilience hanya memiliki pengaruh sebesar $32,7 \%$ sedangkan sisanya merupakan pengaruh faktor lain. Selain mathematical resilience, banyak

penelitian yang menunjukkan bahwa kemampuan pemecahan matematika dipengaruhi oleh faktor lain seperti gaya kognitif (Ulya, 2015), kecemasan dan self efficacy (Kurniawati, 2014), motivasi berprestasi (Aspriyani, 2017) dan IQ (Karsim, Suyitno, \& Isnarto, 2017).

\section{SIMPULAN}

Berdasar pada analisis hasil penelitian, diperoleh simpulan sebagai berikut yaitu terdapat pengaruh mathematical resilience terhadap kemampuan pemecahan masalah matematis siswa kelas XI IPS di MA AlIshlah Bilapora Barat Ganding Sumenep. Mathematical resilience berpengaruh terhadap kemampuan pemecahan masalah matematis siswa sebesar $32,7 \%$ sedangkan sisanya yaitu $67,3 \%$ dipengaruhi oleh

variabel lain di luar penelitian dan diperoleh koefisien regresi sebesar1,297 yang berarti mathemtical resilience berpengaruh positif terhadap kemampuan pemecahan masalah matematis siswa. Berdasarkan penelitian terhadap subjek penelitian ini, siswa dengan mathematical resilience tinggi dapat menyelesaikan soal pemecahan masalah dengan interpretasi, strategi, dan ketepatan yang lebih baik daripada siswa dengan mathematical resilience sedang.

Subjek penelitian yang ditemukan dalam penelitian ini hanya mencakup siswa dengan mathematical resilience tinggi dan sedang, belum mencakup kategori rendah. Oleh karena itu, untuk penelitian selanjutnya perlu meneliti siswa dengan mathematical resilience rendah yang mungkin dapat diperoleh dari populasi yang lebih besar sehingga dapat memperoleh data yang lebih akurat. Karakteristik siswa seperti perbedaan gender dan faktor lingkungan juga perlu digali dengan lebih baik pada penelitian selanjutnya. 


\section{DAFTAR RUJUKAN}

Akbar, P., Hamid, A., Bernard, M., \& Sugandi, A. I. (2018). Analisis kemampuan pemecahan masalah dan disposisi matematik siswa kelas xi sma putra juang dalam materi peluang. Journal Cendikia: Jurnal Pendidikan Matematika, 2(1), 144-153.

Aspriyani. (2017). Pengaruh motivasi berprestasi siswa terhadap kemampuan pemecahan masalah matematis. Jurnal Penelitian dan Pembelajaran Matematika, 10(1), 17-23.

Cahyani, E. P., Wulandari, W. D., Rohaeti, E. E., \& Fitrianna, A. Y. (2018). Hubungan antara minat belajar dan resiliensi matematis terhadap kemampuan pemahaman matematis siswa kelas viii smp. Numeracy, 5(1), 49-56.

Dilla, S. C., Hidayat, W., \& Rohaeti, E. A. (2018). Faktor gender dan resiliensi dalam pencapaian kemampuan berpikir kreatif matematis siswa sma. Journal of Medives: Journal of Mathematics Education IKIP Veteran Semarang, 2(1), 129-136.

Harahap, E. R., \& Surya, E. (2017). Kemampuan pemecahan masalah matematis siswa kelas vii dalam menyelesaikan persamaan linear satu variabel. Edumatica, 7(1), 44-54.

Hutahuruk, A. J. B. (2019). Perilaku resiliensi matematis mahasiswa melalui model problem-based learning dengan pendekatan metakognitif. SEPREN: Journal of Mathematics Education and Applied, $1(1), 7-16$.

Johnston-Wilder, S., \& Lee, C. (2010). Developing mathematical resilience. In BERA Annual Conference 2010. University of Warwick.

Johnston-Wilder, S., Lee, C., Garton, L., Goodlad, S., \& Brindley, J. (2013). Developing coaches for mathematical resilience. In ICERI 2013 : 6th International Conference on Education, Research and Innovation. Seville, Spain.

Karsim, Suyitno, H., \& Isnarto. (2017). Influence of IQ and mathematical disposition toward the problem solving ability of learners grade VII through PBL learning model with the assistance LKPD. Unnes Journal of Mathematics Education, 6(3), 532-539.

Kemendikbud. Peraturan Menteri Pendidikan dan Kebudayaan No.22 tahun 2016 (2016).

Kooken, J., Welsh, M. E., McCoach, D. B., Johnston-Wilder, S., \& Lee, C. (2016). Development and validation of the mathematical resilience scale. Measurement and Evaluation in Counseling and Development, 49(3), 217-242.

Kurnia, H. I., Royani, Y., Hendiriana, H., \& Nurfauziah, P. (2018). Analisis kemampuan komunikasi matematik siswa smp ditinjau dari resiliensi matematik. Jurnal Pembelajaran Matematika Inovatif, $1(5), 933-940$.

Kurniawati, A. D. (2014). Pengaruh kecemasan dan self efficacy siswa terhadap kemampuan pemecahan masalah materi segiempat siswa kelas vii mts negeri ponorogo. Jurnal MATHEdunesa, 3(2), 36-41.

Maharani, S., \& Bernard, M. (2018). Analisis hubungan resiliensi matematik terhadap kemampuan pemecahan masalah siswa pada materi lingkaran. Jurnal Pembelajaran Matematika Inovatif, 1(5), 819-826.

NCTM. (2002). Principles and standards for school mathematics. Reston V.A: NCTM.

NCTM. (2016). The trig/calculus problem of the week scoring rubric for students. Retrieved from https://www.nctm.org/mathforum/

OECD. (2019). PISA 2018 results: combined executive summaries (Vol. I).

Sugiyono. (2017). Metode penelitian kombinasi. Bandung: Alfabeta.

Ulya, H. (2015). Hubungan gaya kognitif dengan kemampuan pemecahan masalah matematika siswa. Jurnal Konseling GUSIJANG, 1(2).

Utami, R. W., \& Wutsqa, D. U. (2017). Analisis kemampuan pemecahan masalah matematika dan self- 
efficacy siswa smp negeri di kabupaten ciamis. Jurnal Riset Pendidikan Matematika, 4(2), 166-175. Yeager, D. S., \& Dweck, C. S. (2012). Mindsets that promote resilience: When students believe that personal characteristics can be developed. Educational Psychologist, 47(4), 302-314.

Zanthy, S. L. (2018). Konstribusi resiliensi matematis terhadap kemampuan akademik mahasiswa pada mata kuliah statistika matematika. Jurnal Musharafa, 7(1), 85-93. 